\title{
Didactic basics of ICTs usage in foreign language teaching in non-language higher education institutions
}

\author{
Shchehlova A.* \\ National University of Food Technologies, Kyiv, Ukraine
}

Received: $12.03 .2020 \quad$ Accepted: 27.03 .2020

\begin{abstract}
The article explores the features of modern information and communication technologies implementation in teaching technical English. The specifics of teaching foreign languages for applicants for non-linguistic specialties has its own characteristics, which should be taken into account when constructing and conducting classes. The information society poses new challenges and correspondingly new goals for teachers and applicants to higher education, the achievement of which is ensured by analyzing situational data and creating the environment that would most closely reflect the realities of the modern professional environment, which requires an appropriate level of a foreign language knowledge. It was determined that electronic learning tools act as a catalyst in mastering the material and improve the quality of the educational process. The study analyzed psychological factors that provide an extremely high level of student motivation and form the corresponding priorities in the direction of professional growth. The pedagogical ways of introducing multimedia teaching aids while studying a foreign language are described in detail as a key condition for the fundamental training of a qualified specialist, focused on meeting the needs of the modern market. It is noted that higher education institutions do not yet fully possess educational computer programs and the latest software, which is one of the most pressing problems in the digitalization of the educational process. It is proved that the effectiveness of achieving didactic goals directly depends on the chosen forms and methods of training, and the inclusion of information and communication technologies has such advantages as individualization and intensification of the educational process, an increase in the amount of independent work of the applicant, which is an important component of the Bologna process. In this regard, and with the aim of developing the communication skills of future specialists, ICTs are considered to be the primary element in the training of qualified specialists in economic fields..
\end{abstract}

Key words: integration; distance learning; cognitive processes; differentiated approach; didactic material; educational environment.

\section{Дидактичні основи використання IКТ при викладанні іноземної мови у немовних закладах вищої освіти}

\author{
Щеглова А. 0.
}

Національний університет харчових технологій, Київ, Україна

\begin{abstract}
Анотація. У статті досліджено особливості впровадження сучасних інформаційно-комунікаційних технологій під час вивчення англійської мови технічного спрямування. Специфіка викладання іноземних мов для здобувачів не філологічних спеціальностей має свої особливості, які слід враховувати при побудові та проведенні заняття. Інформаційне суспільство ставить перед викладачами та здобувачами вищої освіти нові виклики та відповідно нові цілі, досягнення яких забезпечується шляхом аналізу ситуативних даних та створення такого середовища, яке б максимально близько відбивало реалії сучасного професійного середовища, яке вимагає належного рівня володіння іноземною мовою. Визначено, що електронні засоби навчання виступають каталізатором при засвоєнні матеріалу та загалом вдосконалюють якість навчальновиховного процесу. У ході дослідження проаналізовано психологічні фактори, які забезпечують надзвичайно високий рівень мотивації студента та фрормують відповідні пріоритети у напрямку професійного зростання. Детально схарактеризовані педагогічні шляхи впровадження мультимедійних засобів навчання під час вивчення іноземної мови як ключової умови фундаментальної підготовки кваліфікованого фахівця, орієнтованого на задоволення потреб сучасного ринку. Зазначено, що заклади вищої освіти наразі не володіють в повній мірі навчальними комп'ютерними програмами та новітнім програмним забезпеченням, що
\end{abstract}

Corresponding Author: Shchehlova Alla Oleksandrivna, Tel. +38097 29735 79. E-mail: allegro89@bigmir.net National university of food technologies, Volodymyrska str, 68, Kyiv, Ukraine, 01033.

Відповідальний автор: Щеглова Алла Олександрівна, Тел. +38097 29735 79. E-mail: allegro89@bigmir.net Національний університет харчових технологій, м.Київ, вул. Володимирська, 68, 01033. 
виступає однією із найактуальніших проблем діджиталізації навчального процесу. Доведено, що ефективність досягнення дидактичних цілей напряму залежить від обраних форм та методів навчання, а включеність інформаційно-комунікаційних технологій має такі переваги, як індивідуалізація та інтенсифікація навчального процесу, збільшення обсягу самостійної роботи здобувача, що є суттєвим елементом Болонського процесу. У зв'язку з цим та з метою розвитку комунікативних навичок майбутніх фахівців ІКТ розглядаються як первинний елемент підготовки кваліфікованих спеціалістів економічного профрілю..

Ключові слова: інтегрування; дистанційне навчання; пізнавальні процеси; диференційований підхід; дидактичний матеріал; освітнє середовище.

\title{
Дидактические основы использования ИКТ при преподавании иностранного языка в неязыковых высших учебных заведениях
}

\author{
Щеглова А. А.
}

Национальный университет пищевих технологий, Киев, Украина

\begin{abstract}
Аннотация. В статье исследованы особенности внедрения современных информационно-коммуникационных технологий при изучении английского языка технической направленности. Специфика преподавания иностранных языков для соискателей неязыковых специальностей имеет свои особенности, которые следует учитывать при построении и проведении занятия. Информационное общество ставит перед преподавателями и соискателями высшего образования новые вызовы и соответственно новые цели, достижение которых обеспечивается путем анализа ситуативных данных и создание такой среды, которая бы максимально близко отражала реалии современной профессиональной среды, которая требует надлежащего уровня владения иностранным языком. Определено, что электронные средства обучения выступают катализатором при усвоении материала и совершенствуют качество учебно-воспитательного процесса. В ходе исследования проанализированы психологические факторы, которые обеспечивают чрезвычайно высокий уровень мотивации студента и формируют соответствующие приоритеты в направлении профессионального роста. Подробно охарактеризованы педагогические пути внедрения мультимедийных средств обучения при изучении иностранного языка как ключевого условия фундаментальной подготовки квалифицированного специалиста, ориентированного на удовлетворение потребностей современного рынка. Отмечено, что высшие учебные заведения пока не обладают в полной мере учебными компьютерными программами и новейшим программным обеспечением, что является одной из самых актуальных проблем диджитализации учебного процесса. Доказано, что эффективность достижения дидактических целей напрямую зависит от выбранных форм и методов обучения, а включенность информационнокоммуникационных технологий имеет такие преимущества, как индивидуализация и интенсификация учебного процесса, увеличение объема самостоятельной работы соискателя, что является важным элементом Болонского процесса. В связи с этим и с целью развития коммуникативных навыков будущих специалистов ИКТ рассматриваются как первичный элемент подготовки квалифицированных специалистов экономического профиля.
\end{abstract}

Ключевые слова: интегрирование; дистанционное обучение; познавательные процессы; дифференцированный подход; дидактический материал; образовательная среда.

\section{Bcmyn}

Інформатизація та становлення інформаційного суспільства $€$ прямим результатом глобалізаційних процесів, які наразі є актуальними для кожної країни та кожної галузі. На освіту, як передовий елемент суспільної думки, такі процеси впливають в першу чергу, та розглядаються вченими як передумови для успішного економічного розвитку, адже інтелектуальний потенціал нації вимагає постійних змін, вдосконалень змісту навчально-виховних процесів та імплементації методів навчання на основі інфрормаційних технологій.

Інформація виступає сьогодні найбільш цінним ресурсом, саме тому навчитися правильно ії збирати, обробляти, надійно зберігати, передавати та активно використовувати $є$ важливим умінням членів нового суспільства. Інформаційно-комунікаційні технології з кожним роком стають невіддільною частиною змін, що відбуваються з традиційними технологіями та методами навчання, через активний вплив на процес подання, передачі та засвоєння інфрормації, що надзвичайно суттєво виявляється під час вивчення іноземних мов [1]. Вільна циркуляція даних в інформаційному просторі стає можливою завдяки універсальній глобальній мові, тому в чинних реаліях перед майбутніми спеціалістами постає задача опанування іноземною мовою на такому рівні, який би дозволяв конкурувати на ринку праці. Цифрові ресурси та IКТ - це не тільки швидкий доступ до інформації, це педагогічна потреба 
підвищення ефективності навчання згідно з новими соціальними вимогами [3]. Професійно-ділове спілкування іноземною мовою зобов'язує учасників навчального процесу спрямувати зусилля на використання мовних одиниць без граматичних та стилістичних помилок, що, як показує практика, часто створює складнощі для студентів немовних спеціальностей. Це, в першу чергу, пов'язано 3 психологічними засадами засвоєння матеріалу та специфікою тої галузі чи профрілю, за яким відбувається здобуття вищої освіти [4].

У зв'язку зі значним впровадженням нових підходів та методів навчання іноземних мов, які $є$ цікавішими та більш мотиваційними для слухачів, застосування нових IКТ займає провідні позиції в методиці викладання англійської мови в закладах вищої освіти технічного профрілю [6; 7]. Отже, актуальність даної теми пояснюється необхідністю дослідження психологічних факторів успішного засвоєння мовного матеріалу та особливостей і тактик використання сучасних інфрормаційних технологій на заняттях з англійської мови з метою набуття комунікативної компетенції.

Поняття IKT та їх вплив на формування комунікативних навичок під час вивчення англійської досліджувалося різними вітчизняними і закордонними вченими та науковцями [13; 14; 18]. Багато досліджень з даної проблематики встановили, що ІКТ $€$ ключем до змін навчального процесу, а при викладанні іноземної мови сприяє значному зменшенню часу на засвоєння матеріалу, роблячи його більш зрозумілим, цікавим та всеосяжним [1; 6; 8]. На основі методики з використанням програмноорієнтованих методів відбувається вдосконалення такого важливого аспекту Болонського процесу, як самостійна робота [9; 10], адже студенти за таких умов мають розвивати потребу самостійного пошуку. Факторами, що підвищують мотивацію до навчання з використання технологій цифррового характеру, виступають індивідуалізація навчання, всебічний розвиток особистості через активізацію пізнавальних процесів, диференційований підхід до процесу подання та закріплення інформації в освітньому середовищі [11; 4]. Процес апробування інновацій викликає певний ряд труднощів, серед яких варто зазначити недостатній рівень технічних можливостей та оснащеності навчальних закладів, що значно обмежує наявність таких умов, які б сприяли повному та всебічному впровадженню IКТ на заняттях, а, отже, це у свою чергу створює передумови для проблеми мотивації педагогів до використання комп'ютерних технологій $[13 ; 14 ; 19]$.

Mета роботи: охарактеризувати роль, яку відіграють інформаційно-комунікаційні технології у навчанні іноземної мови здобувачів вищої освіти економічного профілю, а саме вплив мотиваційних факторів та основні педагогічні інструменти інтегрування даних технологій у навчальний процес.

\section{II Матеріал і методи дослідження}

Інтеграційні процеси до світової спільноти, які відбуваються в Україні, та тісні політичні, економічні та культурні взаємозв'язки між країнами розкривають зовсім новий рівень значення володіння хоча б однією іноземною мовою. Українські заклади вищої освіти активно приєднуються до тенденцій європеїзації освіти, де провідним напрямком підготовки фахівця $€$ англійська мова як мова міжнародного спілкування, бізнесу, новітніх технологій. Питання мовної компетенції $€$ нагальним не тільки для здобувачів філологічних спеціальностей. Специфіка викладання іноземної мови в інженернотехнічних та економічних вищих навчальних закладах має вплив на методи та форми навчання та відзначається професійною спрямованістю.

Вивчення іноземної мови відбувається з першого курсу і є обов'язковим протягом всього терміну навчання, таким чином гарантується дидактичний принцип неперервності. Здобувачі в Національному університеті харчових технологій мають можливість також відвідувати майстер-класи та розмовні клуби як додатковий спосіб вдосконалення навичок мовної діяльності та розширення знань. Проте необхідність та важливість знання мови не забезпечується в повній мірі через малу кількість годин, відведених на вивчення дисципліни згідно з програмами підготовки здобувачів. А самостійна робота, яка $є$ інтегральною частиною вищої освіти, не справляється із функцією заповнення тих прогалин, які виникають внаслідок недостатньої кількості тижневих академічних годин та наслідками тих підходів до навчання, які превалювали в закладах загальної середньої освіти. Таким чином, чітко випливає той факт, що мовний прогрес студентів економічних спеціальностей не відповідає темпам та вимогам, які ставить перед ними навчальний процес. 
Однією із проблем при роботі зі студентами економічного та технічного профілю $є$ низький рівень мотивації до вивчення іноземної мови або взагалі її відсутність при чіткому усвідомленні її значущості в їхній майбутній професійній діяльності. Власне процес мотивації має декілька факторів впливу, серед яких виокремлюють наявність практичної мети, впевненість у своїх досягненнях, заохочення з боку оточення, зацікавленість та насолода від процесу навчання та опанування нових знань, захоплення культурою країни, мова якої вивчається $[3,86]$. Мотиви розділяють на такі категорії, як емоційні (в основі - психологічний аспект бажання) та раціональні (в основі - фундаментальні аспекти логіки та розумової діяльності). За іншим підходом виділяють мотиви цілей, через які виражається сутність потреб особистості, та інструментальні мотиви, за допомогою яких відбувається імплементація цілей. Динамічна категорія мотивації поведінки та діяльності у навчальному процесі формується саме цими групами мотивів (рис. 1).

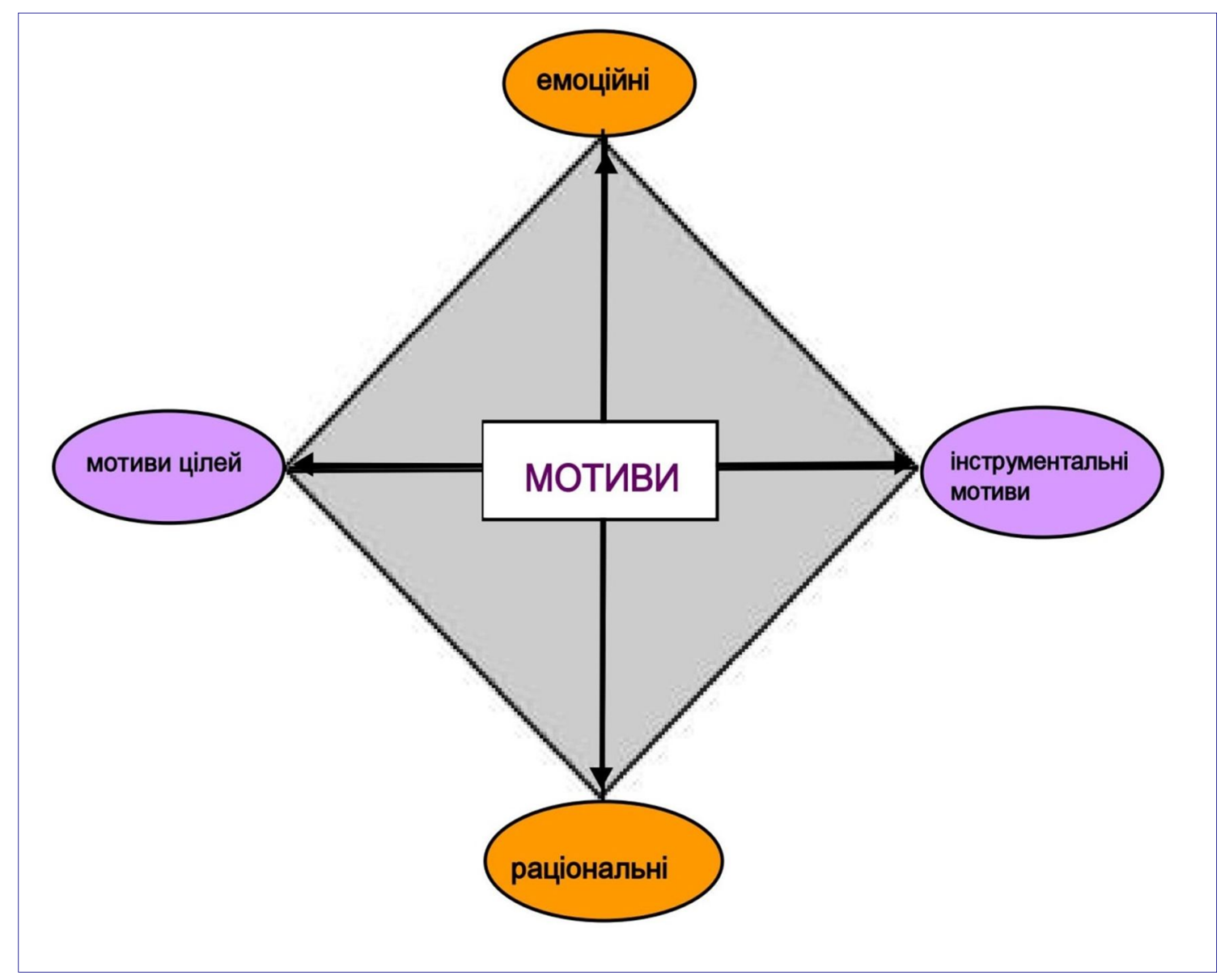

Рис. 1. Визначальні групи мотивів при формуванні мотивації до вивчення іноземної мови

Проблема мотиваційного аспекту в педагогічному процесі $€$ ключовою, саме тому вимагає детального розгляду. Винятковість інтересу до мотивації як провідного чинника регуляції активності особи, їі поведінки та діяльності, формує ефективну педагогічну взаємодію. Вплив позитивної навчальної мотивації проявляє себе в тому, що компенсує недостатньо високі здібності, але високий рівень здібностей до вивчення мови не може зрівноважити відсутність мотиву. Тому невідкладним завданням викладача $€$ пошук результативних способів підвищення мотивації. Оскільки вплив на внутрішній аспект мотивації є обмеженим, то зовнішня мотивація може стати тим інструментом, який спонукатиме слухачів прагнути до досягнення цілей та активізує діяльність. Отже, правильно побудована та організована навчальна діяльність з використанням різноманітних форм, методів і технологій значно підвищує ефективність, якість навчання та мотивацію, сприяючи розвитку когнітивних процесів та інтелектуальної діяльності $[1,30]$. 
Сьогодення відзначається інтенсивним розвитком технологій та інформатизацією відносин в системі суспільства та держави. Трансформації, що відбуваються зі становленням комунікаційних та мережевих технологій, створюють відповідні умови для функціонування інформаційного суспільства. Основною рушійною силою розвитку в таких умовах $є$ рівень інтегрованості до актуальних потоків інформації та доступність актуальних тенденцій до кінцевих споживачів. Такі процеси інформатизації торкаються в першу чергу освіти та мають на меті вдосконалення змісту та фоорм навчального процесу, впровадження нових методів навчання, які здатні вирішити будь-які проблемні ситуації, враховуючи глобальні вимоги [2]. Професійна підготовка майбутніх спеціалістів у галузі економіки стає неможливою без інформаційних технологій, адже сучасна побутова культура, яка починається задовго до того, як студент потрапляє до лав навчального закладу, культурне середовище існування людини тісно пов'язано зі споживанням та продукуванням інформації, яка зараз приймає форму цифрової [5; 10]. Такі трансформації викликані вимогами сучасних тенденцій розвитку та характерними особливостями цифрових технологій в освіті, які додають беззаперечні переваги у вигляді доступності інформації та можливостей швидкого пошуку в реальному часі, спрямування власних бажань та прагнень на цілеспрямоване опанування матеріалу, об'єднання знань з різних галузей науки та бізнесу (рис. 2).

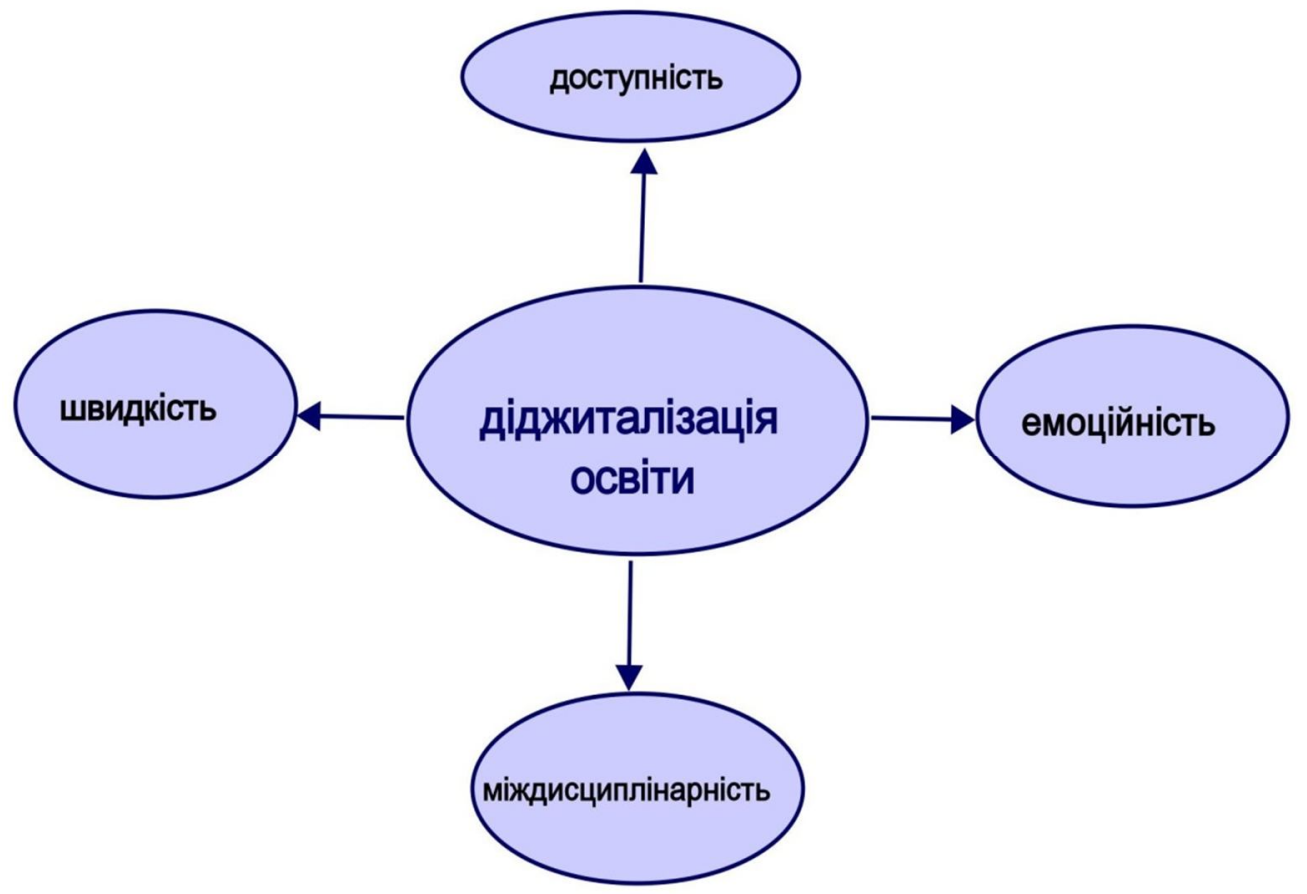

Рис. 2. Ключові характеристики діджиталізації навчального процесу

Високотехнологічність та діджиталізація - феномени, які стали перманентним епіцентром людського розвитку, тому фактично неможливо уявити освітню сферу без впровадження інформаційнокомунікаційних технологій, що охоплюють всі технології, що можна використати для роботи 3 інформацією та спілкування, тобто це може бути комп'ютер, телесон, відеоапаратура, аудіотехнології, проекторне обладнання, спеціалізоване програмне забезпечення. Основною метою ІКТ $є$ підготовка студентів до життєдіяльності в умовах інформаційного суспільства. Будь-який етап навчального процесу може використовувати мультимедійні технології, які слугуватимуть джерелом дидактичного матеріалу чи наочності, інструментом контролю та діагностики, тренувальним засобом чи індивідуальним інформаційним простором студента, не беручи до уваги робочий функціонал ПК, смартфонів та персональних цифрових помічників [4]. Заняття з іноземної мови, що відповідає сучасним вимогам освіти, застосовує IКТ із ціллю сфрормувати у здобувача вищої економічної освіти уміння користуватися різними джерелами інформації, порівнювати та аналізувати дані, створювати та користуватися процедурами вивчення та обробки інформаційних ресурсів англійською мовою. Вирішальне значення IКТ у підвищенні рівня володіння іноземною мовою полягає у формуванні такої особистості, яка готова до міжкультурної співпраці та комунікації на міжнародному рівні. Формування 
комунікативної культури при навчанні англійської мови з використанням мультимедійних технологій дозволяє значно розширити рамки процесів самостійної пізнавальної діяльності слухачів [7]; створити для кожного слухача курсу індивідуальну освітню траєкторію, зважаючи на можливість градуювання ступенів складності матеріалів, адже поділ на групи за рівнями володіння мовою в технічних закладах вищої освіти є надто умовним: часто спостерігається ситуація, коли в одній підгрупі є студенти не тільки різного рівня мовної підготовки, але і різними здібностями до опанування іншомовною компетенцією, що $€$ фактором, який ускладнює процес побудови та проведення заняття. Програмно-комп'ютерна підтримка сприяє полегшеному поданню дидактичного матеріалу та можливості диференціювати задачі та шляхи їх вирішення для студента, враховуючи та розкриваючи індивідуальні потреби та здібності кожного, створюючи атмосферу прихильності та взаємодопомоги на заняттях. IКТ виступає засобом візуалізації, що підвищує ефективність навчального матеріалу для слухачів із більш розвиненим зоровим сприйняттям інформації, розвиваючи при цьому читання, усне та писемне мовлення, сприйняття мови на слух та здатність реагувати на мовленнєвий стимул та критично оцінювати комунікативну ситуацію [6, 490].

\section{III Результати}

Досліджуючи основи навчального процесу в інформаційному суспільстві необхідно акцентувати увагу на особистісну орієнтацією, гнучкість, креативність, що створює відповідні умови для педагогічних шляхів впровадження IKT у вищій школі, а саме проектна та науково-дослідна робота; забезпечення дистанційної форми навчання за допомогою системи віртуального навчального середовища MOODLE; використання електронних підручників та методичних посібників, он-лайн ресурсів, презентацій; моделювання типових ситуацій професійного характеру; розробка систем поточного контролю знань студентів за допомогою спеціального програмного забезпечення; проведення наукових конференцій в режимі он-лайн тощо. Цифрова реальність стає інструментом, який зацікавлює студентів, адже технологічна компетентність $€$ типовою ознакою інформаційного суспільства. Наприклад, технологія доповненої реальності (Augmented Reality / AR) може використовуватися під час заняття з англійської мови в частині подання чи опрацювання нового лексичного матеріалу, встановивши спеціальний додаток та поєднавши текстову інформацію з теми «Відрядження» зі звуком і зображенням можна отримати ефект посиленої реальності; створити власний проєкт готелю чи порівняти послуги, що пропонуються гостям в різних готелях; розробити щоденне меню при активізації лексики з теми «їжа та напої»; спроектувати ідеальний офріс, розмістивши предмети меблів належним чином та описавши переваги такого робочого простору в командах (наприклад, порівняти кабінетну систему із плануванням відкритого типу). Поетапна реалізація інструментів доповненої реальності на заняттях дозволяє перетворити стандартне заняття на досить цікавий формат, який сприятиме залученості студентів будьяких рівнів.

Викладачі також використовують на заняттях відео, і звертаються до таких ресурсів як YouTube та TED, які $€$ часто поповнюваними джерелами навчальних відео на актуальну економічну та ділову тематику, проте варто звернути увагу на той факт, що більшою мірою вони підійдуть для роботи 3 рівнями від В1 та вище.

Іншим потужним інструментом навчання стає телефон, адже зараз складно уявити щоденне життя без даного пристрою. Якщо правильно організувати набір вправ, заняття набуває іншого ступеня креативності та продуктивності. Одним із варіантів може бути проєктна робота: запис коротких програм чи епізодів в групах із заданою регулярністю з метою їх прослуховування та обговорення на занятті. Таким чином відбувається розширення знань бізнес лексики та долається страх публічності. Розмовне заняття також може взяти за основу реальний матеріал пошукової системи. Такий підхід можна втілити, наприклад, в темі «Відрядження. Транспорт.», попросивши студентів забронювати квиток в ту країну, де розташований офіс партнерів по бізнесу, скориставшись англомовною версією сайту. Потім студенти повинні розповісти про тип білету, авіакомпанію та інші деталі поїздки. Такі вправи допомагають практикувати реальну розмовну ситуацію та актуалізувати лексику, і можуть бути розробленими до будь-якої тематики економічного спрямування. Мінідосліження в групах на заняттях — напрямок, який розвиває навички спільної роботи, пошуку релевантної інформації на задану тему з різних ресурсів та представлення матеріалу, технологічну грамотність. Трансформація повідомлень соціальних мереж у 
ділове листування сприятиме розвитку навичок офріційно-ділового стилю листування. Використання диктофону при комунікативних ситуаціях (підготовка до співбесіди, бронювання номеру в готелі чи квитків на літак, замовлення послуг) та виправлення помилок після таких діалогів займає панівне становище серед улюблених усних вправ студентів, адже дозволяє ґрунтовно опрацювати всі важливі моменти вимови, граматики та синтаксису.

\section{IV Обговорення}

Аналіз досліджень дозволив виявити, що ІКТ широко використовуються у всьому світі, адже існує зацікавленість та необхідність у розвитку інноваційних підходів до навчання, яке стає непереривним та доступним кожному.

Ми згодні з авторами, які вважають, що використання можливостей систем інформаційного управління навчанням з боку студентів та викладачів буде сприяти підвищенню якості навчання, відповідати освітній діяльності розвинених країн [9, 490]. ІКТ стають обов'язковим елементом у процесі вивчення іноземної мови та розглядаються як засіб автентичного спілкування, обміну інформацією та власне її джерело. Ефективність навчання з використанням IКТ залежить від чіткості фрормулювання інструкцій та завдань, правильно підібраного матеріалу відповідно до мовленнєвої компетенції студентів та потреб спілкування $[21,136]$. Привабливість ІКТ визначається співпрацею викладача 3 учасниками заняття за допомогою технічного засобу у вигляді телефону, ноутбуку, проєкторної техніки, де викладачеві відводиться роль медіатора, який координує процес творчо-пізнавальної активності, спрямовуючи роботу таким чином, щоб усі студенти долучалися до роботи у ході заняття $77 ; 15 ; 17]$.

Доведено, що професійна комунікативна компетентність здобувачів не фрілологічних спеціальностей вдосконалюється шляхом впровадження ІКТ, проте при цьому чітко виокремлюється низка розбіжностей та проблем [13, 9], пов'язаних із діджиталізацією навчального процесу:

1) відсутність постійного вільного доступу до мережі Інтернет у закладах вищої освіти;

2) непередбачена можливість забезпечення кожного викладача сучасним ПК чи мультимедійною апаратурою;

3) професійна некомпетентність викладачів у використанні IKT;

4) незадовільне технічне обслуговування доступних гаджетів, що 3 часом зношуються i перестають відповідати сучасним тенденціям освіти;

5) недостатня розробка технологій використання програмного забезпечення навчального призначення [12, 171].

За рахунок використання сучасних інформаційно-комунікаційних систем відбувається конструювання вдосконаленого освітнього середовища, чому відповідно сприятиме розвиток матеріально-технічної бази навчальних закладів. В контексті глобалізаційних процесів та впровадження нових підходів та методів навчання іноземних мов формується нова культура педагогічної праці та вектора взаємодії «викладач-студент» [11].

Проведене нами анкетування студентів щодо використання IKT на заняттях з іноземної мови дозволило виокремити такі переваги:

1. Можливість впливу сучасних медіа та гаджетів на повсякденному рівні, що робить їх використання в навчально-освітньому процесі звичним та зрозумілим.

2. Мобільність та диференційованість при підготовці та проведенні занять.

3. Привабливість IKT не втрачає своєї популярності, роблячи акцент на індивідуалізації навчання.

4. Отримання інформації у формі, що нагадує розважальну, сприяє полегшенню засвоєння знань.

5. Багатоканальність як новий метод отримання інформації [16].

Власне серед викладачів також було проведене опитування, що дозволило виділити ряд переваг:

1. Спонукання до пошуку нетрадиційних форм подачі матеріалу.

2. Автоматизація навчального процесу посередництвом технологічних засобів як на етапі введення, так і на етапі закріплення інформації та контролю знань.

3. Надання ширших можливостей розуміння потенціалу студента та оцінювання його здібностей.

4. Діагностичні комплекси та спеціальні програми дозволяють оперативніше оцінити рівень засвоєння знань, умінь та навичок та внести відповідні корективи за необхідності. 
5. Розвиток пізнавальної самостійності та гармонійної індивідуальності в контексті культурноекономічної глобалізації (розвивальна мета заняття).

6. Реалізація комплексів психологічних та дидактичних принципів.

Заклади вищої освіти активно впроваджують змішане та дистанційне навчання посередництвом системи Moodle, що характеризується доступністю та гнучкістю навчального матерілу, можливістю працювати з даними різних форматів та керувати власними часовими ресурсами. Майже аналогічні результати опитування були отримані іншими дослідниками, зокрема I. Malinina та M. Pun також зазначають, що відбувається перехід від механічного засвоєння знань до оволодіння навичками самостійного пошуку та здобуття знань [10; 17].

3 іншого боку, як показують дослідження В. Ю. Бикова [1; 2], навчальні досягнення, отримані у процесі е-навчання, демонструють необхідність вдосконалення електронних курсів та засобів навчання. Отже, ефективність використання дистанційної форми навчання під час підготовки студентів не філологічних спеціальностей виступає нагальною необхідністю сучасного інформаційного суспільства.

Психолінгвістичні основи іншомовної комунікативної компетенції краще формуються в умовах позитивного ставлення до дисципліни, що вивчається, та психологічного компоненту мотивації.

\section{V Висновки}

Поступовий перехід вищої освіти на новий рівень змінює підходи до навчального процесу та форм і методів його організації. Для ефективної модернізації освітньої галузі, яка має відповідати вимогам інформаційного суспільства та глобальним соціально-економічним трансформаціям, виникає необхідність застосування інформаційно-комунікаційних технологій у процесі викладання іноземної мови студентам немовних спеціальностей.

ІКТ охоплюють сферу технологій обробки інформації за допомогою телекомунікаційних та мультимедійних засобів, які стимулюють інтерес до вивчення іноземних мов, сприяють розвитку здібностей і навичок мультитаскінгу, фрормують інформаційну культуру особистості майбутнього фахівця.

Нові інформаційні технології в єдиному освітньому просторі розглядаються як якісно новий спосіб поширення знань, який також підвищує мотивацію студентів та активність на заняттях, розвиває навички та готовність до самостійного пошуку і вивчення інсрормації, збільшує обсяг культурологічних та лінгвістичних знань. Використання ІКТ допомагає вдосконалювати комунікативні вміння та навички у всіх видах мовленнєвої діяльності, інтенсифрікувати навчальний процес та зробити його диференційованим та індивідуально спрямованим, адже враховується рівень мовної підготовки студентів, темп роботи, що дозволяє дотримуватися принципу доступності та практичності знань. Лінгводидактичний потенціал ІКТ $€$ основою інтерактивності навчання, що свідчить про те, що відбувається гармонійне поєднання традиційних методів навчання та нових, а отже спостерігається дотримання дидактичних принципів науковості, наочності, систематичності, послідовності, активного залучення всіх студентів до навчального процесу, гнучкості та динамічності. Водночас, ефрективна модернізація вищої освіти потребує всеосяжного оновлення технічних засобів навчання та надання вільного доступу до мережі Інтернет суб'єктам навчального-виховного процесу.

Проведення детального аналізу особливостей застосування окремих видів ІКТ у процесі опанування різних лінгвістичних аспектів з метою обрання найбільш ефективних з них є перспективою подальших досліджень.

\section{Бібліографічні посилання}

1. Биков В. Ю. Підвищення значущості інформаційно-комунікаційних технологій в освіті. Педагогіка і психологія. 2009. №1. C. 28-33.

2. Биков В. Ю., Кухаренко В. М., Сиротенко Н. Г., Рибалко О. В., Богачов Ю. М. Технологія створення дистанційного курсу: Навчальний посібник ; за ред. В. Ю. Бикова та В. М. Кухаренка. Київ: Міленіум, 2008. 324 с.

3. Боднар С. В. Використання Інтернет-технологій у системі автономного вивчення професійно-орієнтованої іноземної мови студентами немовних спеціальностей. Інформаційні технології і засоби навчання. 2013. Том 34. № 2. С. 75-81

4. Васильева И. А., Осипова Е. М., Петрова Н. Н. Психологические аспекты применения информационных технологий. Вопросы психологии. 2002. №3. С. 86. 
5. Коваль Т. І. Підготовка викладачів вищої школи: інформаційні технології у педагогічній діяльності: навч.-метод. посіб.. Київ.: Вид. центр НЛУ, 2009. 380 с.

6. Костенко І. Г. Використання Інтернет-ресурсів на уроках англійської мови. Таврійський вісник освіти. 2013. № 1 (41). С. 170-176.

7. Костікова І. І. Роль комп'ютерних технологій в навчанні студентів. Новий колегіум. 2006. № 2 (33). С. 55-63.

8. Кухаренко В. М. Дистанційне навчання. Енциклопедичне видання : навчально-методичний посібник. иїв: ТОВ Редакція «Комп'ютер», 2007. $128 \mathrm{c.}$

9. Лапінський В. Електронні засоби навчального призначення - світовий досвід й українська освіта. Вища освіта України. 2011. №3. C. 487-495.

10. Malinina I. Blended Learning of English Language:Combining Online and Face-to-Face Teaching. Infonomic Society. London, 2012. P. 247-251.

11. Морська Л. І. Інформаційні технології у навчанні іноземних мов : навчальний посібник. Тернопіль: Астон, 2008. 256 с.

12. Нітченко Г.М., Ховрич М.О. Аналіз використання інфрормаційно-комунікаційних технологій у навчальному процесі. Вісник Чернігівського національного педагогічного університету. Серія : Педагогічні науки. 2015. Вип. 130. С. 169-172.

13. Носкова Н. В. Інформатизація системи освіти та проблеми впровадження педагогічних програмних засобів у навчальний процес. Комп'ютер у школі та сім'ї. 2006. №5. С. 7-11.

14. Носкова Н. В. Проблема мотивації педагогів до використання інформаційно-комунікаційних технологій у навчальному процесі. Комп'ютер у школі та сім'ї. 2009. №1. С. 6-10.

15. Палагутина М. А., Серповская И. С. Инновационные технологии обучения иностранным языкам. Проблемы и перспективы развития образования: материалы междунар. заоч. науч.конф. Пермь : Меркурий, 2011. С. 156-159.

16. Плугатарьова О. І. Використання інтернет-контенту під час вивчення іноземної мови. Англійська мова та література. 2011. №11. C. 8-13.

17. Pun M. Use of Multimedia Technology in English Language Teaching. Crossing the Border: International Journal of Interdisciplinary Studies. 2013. №1. C. 29-38.

18. Сысоев П. В., Евстигнеев М. Н. Современные учебные Интернет-ресурсы в обучении иностранному языку. Иностранные языки в школе. № 6. 2008. С. 2-9.

19. Титова С. В. Информационно-коммуникационные технологии в гуманитарном образовании: теория и практика. Пособие для студентов и аспирантов языковых факультетов университетов и вузов. М.: Издательский дом «КвинтоКонсалтинг», 2009. 240 c.

20. Хуторской А. В. Современная дидактика : учеб. пос. / А.В. Хуторской. - 2-е изд. перераб. - М. : Высш. шк., 2007. $639 \mathrm{c}$.

21. Чередніченко Г. А., Шапран Л. Ю., Куниця Л. І. Мультимедійні технології у процесі викладання дисципліни «Іноземна мова» у вищих технічних навчальних закладах. Наукові записки. Серія: Педагогіка. Тернопільський національний педагогічний університет ім. В. Гнатюка, 2011. № 4. С. 134-138.

\section{References}

1. Bykov, V.Yu. (2009), Pidvyshchennia znachushchosti informatsiino-komunikatsiinykh tekhnolohii v osviti. Pedagogy and psychology, Iss. 1, 28-33. [in Ukrainian]

2. Bykov, V.Yu., Kukharenko, V.M., Syrotenko, N.H., Rybalko, O.V., Bohachov, Yu.M. (2008), Tekhnolohiia stvorennia dystantsiinoho kursu, Kyiv, Millennium, 324 p. [in Ukrainian]

3. Bodnar, S.V. (2013), Vykorystannia Internet-tekhnolohii u systemi avtonomnoho vyvchennia profesiino-oriientovanoi inozemnoi movy studentamy nemovnykh spetsialnostei, Information technology and training tools, Iss. 2 (34), 75-81. [in Ukrainian]

4. Vasilieva, I.A., (2002), Psihologicheskie aspektyi primeneniya informatsionnyih tehnologiy, Issues of psychology, Iss. 3, 86. [in Russian]

5. Koval, T.I, (2009), Pidhotovka vykladachiv vyshchoi shkoly: informatsiini tekhnolohii u pedahohichnii diialnosti, Kyiv, NLU publishing center, 380 p. [in Ukrainian]

6. Kostenko, I.H., (2013), Vykorystannia Internet-resursiv na urokakh anhliiskoi movy. Tavriiskyi visnyk osvity, Iss. 1 (41), 170176. [in Ukrainian]

7. Kostikova, I.I., (2006), Rol kompiuternykh tekhnolohii v navchanni studentiv. Novyi kolehium, Iss. 2 (33), 55-63. [in Ukrainian]

8. Kukharenko, V.M., (2007), Dystantsiine navchannia. Entsyklopedychne vydannia, Kyiv, «Computer» Publishing center, 128 p. [in Ukrainian]

9. Lapinsky, V., (2011), Elektronni zasoby navchalnoho pryznachennia - svitovyi dosvid y ukrainska osvita. Higher education of Ukraine, Iss. 3, 487-495. [in Ukrainian]

10. Malinina, I., (2012), Blended Learning of English Language:Combining Online and Face-to-Face Teaching. Infonomic Society, London, 247-251. [in English]

11. Morska, L.I., (2008), Informatsiini tekhnolohii u navchanni inozemnykh mov, Ternopil, Aston, 256 p. [in Ukrainian]

12. Nitchenko, H.M., Khovrych, M.O., (2015), Analiz vykorystannia informatsiino-komunikatsiinykh tekhnolohii u navchalnomu protsesi. Journal of Chernihiv national pedagogical university, Iss. 130, 169-172. [in Ukrainian]

13. Noskova, N.V., (2006), Informatyzatsiia systemy osvity ta problemy vprovadzhennia pedahohichnykh prohramnykh zasobiv u navchalnyi protses. Computer in school and family, Iss. 5, 7-11. [in Ukrainian]

14. Noskova, N.V., (2009), Problema motyvatsii pedahohiv do vykorystannia informatsiino-komunikatsiinykh tekhnolohii u navchalnomu protsesi // Computer in school and family, Iss. 1, 6-10. [in Ukrainian] 
15. Palagutina, M.A., (2011), Innovatsionnyie tehnologii obucheniya inostrannyim yazyikam. Problems and prospects of the development of education: papers of international extramural scientific conference, Perm, Merkuriy, 156-159. [in Russian]

16. Pluhatarova, O.l., (2011), Vykorystannia internet-kontentu pid chas vyvchennia inozemnoi movy. English language and literature, Iss. 11. 8-13. [in Ukrainian]

17. Pun, M., (2013), Use of Multimedia Technology in English Language Teaching. Crossing the Border: International Journal of Interdisciplinary Studies, Iss. 1. 29-38. [in English]

18. Syisoev, P.V., Evstigneev, M.N., (2008), Sovremennyie uchebnyie Internet-resursyi v obuchenii inostrannomu yazyiku. Foreign languages at school, Iss. 6, 2-9. [in Russian]

19. Titova, S.V., (2009), Informatsionno-kommunikatsionnyie tehnologii v gumanitarnom obrazovanii: teoriya i praktika. Posobie dlya studentov $i$ aspirantov yazyikovyih fakultetov universitetov i vuzov, Moscow, Kvinto-Consulting, 240 p. [in Russian]

20. Hutorskoy, A.V., (2007), Sovremennaya didaktika, Moscow, Higher school, 639 p. [in Russian]

21. Cherednichenko, H.A., Shapran, L.Yu., Kunytsia, L.I., (2011), Multymediini tekhnolohii u protsesi vykladannia dystsypliny «Inozemna mova» u vyshchykh tekhnichnykh navchalnykh zakladakh. Scientific notes. Series: Pedagogy, Ternopil National Pedagogical University after V. Hnatyuk, Iss. 4, 134-138. [in Ukrainian]
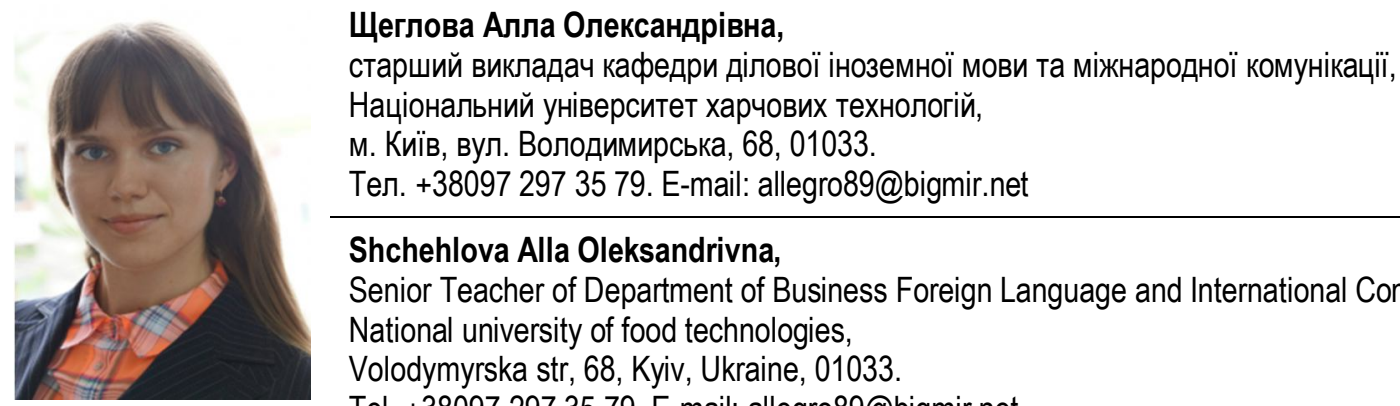

\section{Shchehlova Alla Oleksandrivna,}

Senior Teacher of Department of Business Foreign Language and International Communication,

National university of food technologies,

Volodymyrska str, 68, Kyiv, Ukraine, 01033.

Tel. +38097 29735 79. E-mail: allegro89@bigmir.net

ORCID: 0000-0002-6632-2753

Researcher ID: F-5469-2019

\section{Citation (APA):}

Shchehlova, A. (2020). Didactic basics of ICTs usage in foreign language teaching in non-language higher education institutions.

Engineering and Educational Technologies, 8 (1), 95-104. doi: https://doi.org/10.30929/2307-9770.2020.08.01.08

Цитування (ДСТУ 8302:2015):

Щеглова А. О. Дидактичні основи використання ІКТ при викладанні іноземної мови у немовних закладах вищої освіти I Інженерні та освітні технології. 2020. Т. 8. № 1. С. 95-104. doi: https://doi.org/10.30929/2307-9770.2020.08.01.08

Обсяг статmi: $\quad$ сторінок - 10 ; умовних друк. аркушів - 1,448 . 